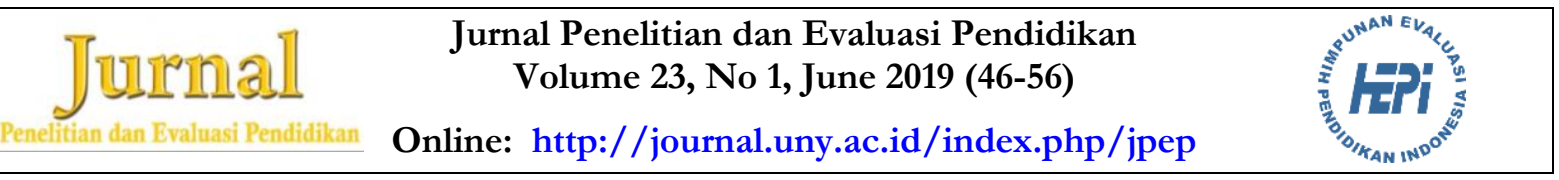

\title{
THE IMPLEMENTATION OF ATTITUDE ASSESSMENT IN CURRICULUM 2013 AT ELEMENTARY SCHOOLS
}

\author{
Ikbya Ulumudin
}

The Center for Research on Education Policy and Culture, Ministry of Education and Culture

\section{Sisca Fujianita}

The Center for Research on Education Policy and Culture, Ministry of Education and Culture

\begin{abstract}
This study is aimed at describing the implementation of attitude assessment conducted by teachers starting from the assessment planning, implementation, results processing, its utilization, and the follow-up. This study employed a qualitative and quantitative method. The subject was elementary school teachers in Bekasi city who had taught in classes applying Curriculum 2013. The data were collected using questionnaires and focus group discussions. The result shows that the implementation of attitude assessment had not been done optimally because of teachers' lack of understanding. Besides, too many techniques of attitude assessment cause teachers to need a lot of time to learn and conduct the assessment. In Curriculum 2013, students' involvement is emphasized, yet most students were quite passive in class, and there was no dynamic and active discussion in the learning process. It means teachers need to apply different methods to encourage students to be more active. Lastly, the utilization and follow-up of the assessment results were not optimal. Some recommendations that can be proposed are: (1) schools are hoped to be able to provide independent training for the implementation of assessment in Curriculum 2013; (2) mandatory attitude assessment required to be done by each subject teacher is observation, while other required assessments are done by the classroom teacher; (3) variables in attitude assessment needs to be completed and clearly stated especially in social aspects (KI-2), which are accepting and responding; (4) there should be a detailed description of attitude assessment in students' reports.
\end{abstract}

Keywords: attitude assessment; assessment planning; assessment implementation; assessment result processing; assessment result utilization; assessment result follow-up

Permalink/DOI: http://dx.doi.org/10.21831/pep.v23i1.23391

\author{
Contact Ikhya Ulumudin \\ ikbya.puslitjak@gmail.com \\ The Center for Research on Education Policy and Culture, Research and Development \\ Agency, Ministry of Education and Culture of Republic of Indonesia \\ Jl. Jenderal Sudirman, Komplek Kemendikbud gedung E lantai 19, Senayan, Jakarta \\ 10270, Indonesia
}




\section{Introduction}

The government, through the Ministry of Education and Culture (MoEC), continues making innovations in education, one of them is by renewing the curriculum of primary and secondary education. Gradually, starting in 2013, the government has implemented Curriculum 2013 at primary and secondary education. It is done as a way to control the education quality so that Indonesia can have generations which will be able to compete worldwide.

The changes in the curriculum affect the assessment system. Conducting the assessment of learning outcomes is a way done to control education quality. According to Clements and Cord, assessment is an essential component in the learning process and its' environment, and it also has a role in knowing the learning outcomes. Assessment is hoped to be the instrument of the quality insurance, quality control, and quality improvement in the education system as in the scale of class or school (Sutama, Sandy, \& Fuadi, 2017). Assessment is a series of activities to obtain qualitative and quantitative information in the beginning, ongoing, or at the end of the learning process, aimed to evaluate and diagnose things need to be fixed so that teachers and students can review, plan, and apply the action to be done next to achieve the learning goals (Purnomo, 2013).

Assessment of learning outcomes in primary and secondary education level consists of the assessment conducted by teachers, schools, and government. It covers the assessment of attitude, knowledge, and skill. This study will further discuss the elementary school attitude assessment that is conducted by teachers. Assessment of learning outcomes is conducted by the teacher to monitor and evaluate the learning process, learning progress, and also to improve student's learning outcomes continuously. Moreover, the attitude assessment is specifically conducted by the teacher to obtain the descriptive information of student's attitude (Regulation of the Minister of Education and Culture of Republic of Indonesia No. 23 of 2016 on Educational Assessment Standard).
The authentic assessment is used as an assessment system in Curriculum 2013. Authentic assessment is a significantly meaningful measurement of a student's learning outcomes in the attitude, knowledge, and skill aspect. It can describe the student's competencies more comprehensively and objectively, even when the student has completed his education (Wuryani \& Irham, 2014). However, the changes in the assessment system caused problems for the teachers. Utsman (2014) in his study mentioned that the changes of the assessment system in Curriculum 2013 confused the teachers because the traditional assessment system which was already established and easy to conduct had to be changed with the alternative assessment in the form of authentic assessment. His study described that many teachers have difficulty in understanding the Curriculum 2013 assessment technique, especially on how to do the authentic assessment. Most teachers know the assessment but do not know how to apply and to adjust it as demanded in Curriculum 2013. Another study stated that some teachers still have difficulty in applying the Curriculum 2013; the greatest one faced by teachers is in applying the authentic assessment (Haryana \& Gimin, 2015).

In Curriculum 2013, in addition to knowledge and skill assessment, attitude assessment explicitly has to be done as well by the teacher. It adds to the difficulty faced by the teacher, because in the previous curriculum, teachers were not asked to conduct the attitude assessment. Yulia, Bakhtiar, and Fauzi (2017) mentioned that teachers' problems in applying the assessment are its' complexity and the limited amount of time. Besides, Mahmud (2014) states in his study, "all teachers in Delima Cluster have difficulty in conducting an assessment, especially the attitude assessment, which is considered as a complex assessment."

Attitude assessment is needed to face global competition so that the graduates can be successful. Someone's success is influenced by some factors, one of which is his attitude. It can be seen from a survey con- 
ducted by Thomas J. Stanley, Ph.D. that is written in his book, The Millionaire Mind. The survey was conducted in the United States of America with a total of 1001 respondents, of which 733 respondents were billionaires. Based on the research, there are 30 determinants of success. The top 10 determinants are attitude competencies such as: being honest, discipline, socializing skill, having a supportive partner, work harder than others, love what is done, great and strong leadership, passionate and competitive personality, good life management, and the ability to present ideas and products (Hatmoko, 2016).

Attitude assessment is intended as an assessment of student's attitude in the learning process, consisting of spiritual attitude (Core Competency-1/KI-1) and social attitude (Core Competency-2/KI-2). Attitude assessment has different characteristics from knowledge and skill assessment, so the techniques are also different. In this case, the attitude assessment focuses more on fostering students' behavior to build their character. Attitude assessment consists of the main assessment and supporting assessment. Main assessment is obtained by daily observation, which is written in the daily journal. Supporting assessment is obtained by doing self and peer assessment, which its result can be used as a confirmation of the assessment done by the teacher. The assessment technique used is observation through an interview, anecdotal record, and incidental record as the main assessment element. The spiritual competencies (KI-1) which are being observed are accepting, doing, and respecting the religion they adhere to. Meanwhile, the social (KI-2) ones include several attitudes, among others: honest, disciplined, responsible, polite, caring, and confident in interacting with family, friends, neighbor, and the country (Directorate for the Development of Elementary School, 2016). Preparing a generation with excellent characters should be started since their early age, which means elementary schools. A study conducted by Riscaputantri and Wening (2018) shows the affective descriptions or student's attitudes are (1) based on the affective levels proposed by Krathwohl, Bloom and Masia: characterizing level $42.9 \%$, organizing $50.9 \%$, judging $6.2 \%$, and accepting and responding $0 \%$; (2) based on Curriculum 2013: on excellent category $62 \%$, good $38 \%$, adequate $1 \%$ and poor $0 \%$.

Process of the attitude assessment starts from planning, implementation, processing, utilization, and the follow-up. The planning is done based on KI-1 and KI-2. The teacher plans and decides the attitude being assessed in the learning process. In addition, for the assessment outside the learning process, the teacher observes the natural behavior. The implementation of attitude assessment is adjusted to the learning approach taken during and outside the learning process. The result of attitude assessment will be discussed and reported in the form of a descriptive score. The result is utilized to get the information of student's attitude, identify the progress, and do the follow-up.

Based on the description above, the researchers are prompted to conduct a study of the implementation of the attitude assessment in Curriculum 2013 at elementary schools. This study aimed to describe the implementation of attitude assessment conducted by teachers starting from the assessment planning, the implementation, the assessment results' processing, its' utilization, and the follow-up.

\section{Research Method}

The study was conducted on August 8-10, 2018, in Bekasi, West Java. This study used a mixed-method (qualitative and quantitative method), and the data were collected using questionnaires and focus group discussions. The questionnaires were online and could be accessed using a smartphone application with google drive as the basis. Respondents could fill in the questions in the instruments through https://goo.gl/forms/ AEwhFq130oS1acn23. The regional education office distributed the instruments page (URL link) through the elementary school principals group chat on What's App (WA). 
Then, the principals distributed it to the teachers in their own school. The FGDs were conducted in the discussion room of Bekasi City Education Regional Office, inviting qualified-teachers who were selected by the education regional office staff.

The subject were elementary school teachers, both public and private school in Bekasi, who had taught in class applying the Curriculum 2013. The subjects are the informants in the Focussed Group Discussion (FGD) and questionnaire respondents. A total of eight persons, consisting of six elementary school teachers, one elementary school supervisor, and one staff of the regional education office managing the elementary level, were involved as the informants in FGD. The staff of regional education office selected the informants with some provisions, such as, the selected teacher is an instructor of Curriculum 2013, or he/she is the one who made the questions for the National-Standard School Examination questions or the one who had an experience of teaching the class applying Curriculum 2013. There are a total of 1,528 questionnaire respondents, who came from the teachers of Bekasi public and private elementary school which have been implementing Curriculum 2013. The regional education office coordinated the selection of the questionnaire respondents.

The questionnaire used closed questions with three choices of answers: understood, partly understood, not at all understood. The questionnaire-filling is aimed at finding out teachers' understanding (1) in making an instrument format of attitude assessment, (2) on different techniques of attitude assessment, and (3) in processing and reporting the attitude assessment. Whereas, the FGD guidance consisted of three opened questions: (1) confirmed and explored teachers' questionnaire answer; (2) discussed teachers' tendency in answering particular choices; and (3) identified the difficulties and problems faced by teachers in conducting the attitude assessment. Thus, the FGD aimed to confirm and explore teachers' questionnaire answer and to identify the difficul- ties and problems faced by teachers in planning, implementing, processing the results, utilizing, and doing the follow-up of the attitude assessment.

The field research procedure consisted of three steps. First, the researchers came to the regional education office to ask for permission to conduct a study and ask the regional education office to distribute the questionnaire to elementary school teachers, with the letter of introduction about the appeal of filling out the questionnaire from the head of regional education office being inserted. Second, the result of the processedquestionnaire can be seen directly on Google Drive. Third, the distribution of the questionnaire was confirmed, and the answer was explored through FGD. Last, in FGD, the researchers have also identified the difficulties and problems faced by teachers in planning, implementing, processing the results, utilizing and doing the follow-up of the attitude assessment.

The data were analyzed using a quantitative descriptive technique in the form of a percentage of each question's answer. It was done in several steps: (1) analyzing the questionnaire answers; (2) conducting triangulation of the questionnaire results by confirming to FGD informants; (3) identifying and exploring the cause of the tendency of respondents' answers; (4) identifying the difficulties and problems faced by teachers in planning, implementing, processing the results, utilizing, and doing the follow-up of the attitude assessment while conducting triangulation of the three informants (teachers, supervisors, and the staff of regional education office); (5) drawing conclusions of the research.

\section{Findings and Discussion}

\section{Findings}

Findings are elaborated based on the purpose of the study, which is to describe the implementation of attitude assessment conducted by the teacher, starts from planning, implementing, processing the results, utiliz- 
ing and doing the follow-up. Each step is explained as follows.

\section{Assessment Planning}

The planning of attitude assessment is a teacher's preparation in making instruments or assessment format of each attitude assessment technique. The techniques are observation, self-assessment, and peer assessment. The instruments of observation are unstructured observation form, structured observation form, social and spiritual journal. While the instruments of self-assessment are self-assessment form and for the peer assessment is peer assessment form. The attitude assessment instruments cover the spiritual aspect (KI-1) and social aspect (KI-2), which appear naturally during the learning process inside or outside the classroom. KI-1 which were being observed was accepting, doing, and respecting the religion students adhere to. Meanwhile, KI-2 which were being observed included attitude among others: honest, disciplined, responsible, polite, caring, and confident in interacting with family, friends, neighbor, and the country.

Planning an attitude assessment requires teachers' understanding of the KI-1 and KI-2 indicators which are being observed, so teachers can easily make the attitude assessment instruments. However, many teachers did not understand it. Based on the questionnaire results, a total of $45.22 \%$ elementary school teachers in Bekasi City understood how to elaborate the indicators of KI-1 and KI-2, and turn it into the form of an assessment instrument. Meanwhile, $52.03 \%$ of teachers partially understood, and $2.75 \%$ did not understand. In FGD, it was revealed that teachers' lack of understanding was specifically in two things: the elaboration of attitude aspect indicator into the instrument and the making of scoring rubrics.

First, the teacher had not been able to elaborate the attitude aspect indicator into the instrument. Teachers found it difficult to elaborate the indicators of spiritual and social aspect into questions/statement or assessment form. For example, in turning the indicators of spiritual aspect (accepting, doing, and respecting the religion students adhere to) into questions/statement or assessment form. As well as the social aspect, it was complicated for teachers to turn the indicators (honest, disciplined, responsible, polite, caring, and confident in interacting with family, friends, neighbor, and the country) into questions/statement or assessment form.

Teachers thought of some solutions to overcome those problems, such as used assessment instruments with the same format as the example given by the Directorate for Development of Elementary School in Panduan Penilaian Sekolah Dasar. The majority of teachers used precisely the same self and peer assessment instruments as the sample in the guidance book without any development.

Second, teachers found difficulties in making the scoring rubric of attitude assessment. For example, in KI-1 attitude assessment, there was a student who prays regularly but also often disturbs other friends who are praying. On the other hand, he always thanks others when receiving help or gifts. The teacher was confused about what score (excellent, very good, adequate, or poor) to give because, in one particular variable, the student had strengths and weaknesses. It created different perceptions among teachers in deciding the attitude score.

According to teachers, the social aspect indicators which include honest, disciplined, responsible, polite, caring, and confident in interacting with family, friends, neighbor, and the country, need to add some more variables to fit the Curriculum 2013 learning system. Curriculum 2013 learning emphasizes on students' involvement. However, in fact, most students were passive during the learning process; only a few of them were active. It made the learning atmosphere becoming less active. The research conducted by Retnawati (2015) concluded that the main difficulty in the implementation of scientific learning was to make the student become more active and applying $5 \mathrm{M}$. 
In the FGD, it was revealed that in guidance book, there had not been explicitly contained information on how to determine the attitude score. In the guidance book, it was only stated about the scoring predicate, namely A (excellent), B (good), C (adequate), and $\mathrm{D}$ (poor) but there was no explanation on how a student could get a particular score. Teachers hope that the information on how to make the scoring rubrics could be put in the guidance book, to minimize the different perceptions among teachers.

Teachers' competencies to comprehend the various attitude assessment technique could affect their competency in doing the assessment. The same thing was mentioned in the research done by Retnawati (2015) that "teachers' understanding of social attitude assessment significantly affected their skill in implementing social skill assessment." For this reason, teachers should improve their understanding of attitude assessment continuously, and school should provide training of Curriculum 2013 assessment for teachers independently.

\section{Assessment Implementation}

Teacher implements attitude assessment during and out of the learning process. The assessment technique consists of the main assessment and supporting assessment. Main assessment is obtained by daily observation, which is written in the daily journal. The assessment technique used is observation through an interview, anecdotal record, and incidental record. The supporting assessment is obtained by doing self and peer assessment, which its result can be used as a confirmation of the assessment done by the teacher. The technique used is distributing questionnaires, both in self and peer assessment.

Teachers are required to master various assessment techniques, both main and supporting assessment. However, not all elementary school teachers mastered those techniques. From the questionnaires, it is known that $54 \%$ of elementary school teachers had a good understanding of the assessment techniques, $42.54 \%$ with partial under- standing, and $2.88 \%$ did not understand the techniques. In FGD, it was mentioned that observation by making an incidental record was the most used assessment technique. While interview, self-assessment, and peer assessment were rarely used because the teacher did not really understand the techniques.

Observation techniques by making incidental record were used by teachers to record students" "extreme" attitude (good and bad attitude). Based on FGD, steps done by teacher in making incidental record observation were: (1) students' attitude which was recorded in journal were the very good and the very bad ones and related to the attitude items of spiritual and social aspect; (2) if student has had unfavorable records, and if on another occasion the student has shown good attitudes in the same indicator, then in the journal it was written that the student has been good or even very well; (3) records in the journal were not limited to the bad and good attitude, but also the development towards the expected attitude; (4) based on the journal, teacher made a description of students' attitude assessment in a semester.

Two supporting attitude assessments function as data confirmations, namely selfassessment, and peer assessment. Self-assessment is an assessment technique where student assesses themselves by identifying their strengths and weaknesses in behaving. Meanwhile, peer assessment is an assessment technique where the student assesses another students' attitude. Not all teachers in Bekasi City conducted self and peer assessment. Sutama et al. (2017) mentioned the same thing on his study, "in conducting the attitude assessment, teachers only used observation technique and wrote it in the daily journal."

Self and peer assessment were usually conducted at the end of the semester because the assessment results were used as data confirmation of student attitude development during one semester. Steps done by teachers in conducting self and peer assessment were: (1) conducted self-assessment first and then peer assessment in the same 
period of time; (2) in peer assessment each student usually assessed one to two other students; (3) the results of self and peer assessment were used as confirmation data by matching it with the result of observation, and then used to determine the attitude score for student's report.

Based on these reasons, teachers want the assessment that has to be done by all teachers is the assessment using the observation technique only. If a classroom teacher does self and peer assessment, this will save time, because, in the authentic assessment, there are a lot of techniques and students to be assessed. It is in line with the study conducted by Merta, Suarjana, and Mahadewi (2015) which found that "teachers' difficulties in conducting authentic assessment were a large number of students, many assessment techniques to be done, and the availability of time to conduct the assessment."

\section{The Processing of Assessment's Results}

Results of attitude assessment were recapitulated every semester. The result would be discussed and reported in the form of description. Steps in making a description score were: (1) classroom teacher and subject teachers classified and marked the records of students' attitude written in the journal, both spiritual and social aspects; (2) classroom teachers recapitulated the students' attitude within one semester (the period can be adjusted according to the school consideration); (3) classroom teachers collected the short description of students' attitude from religious teacher and PE teacher and also from the school residents (extracurricular teachers, librarian, janitors, and also school guards); (4) classroom teacher inferred and made the final description of students spiritual and social achievement.

Elementary school teachers were still lack of understanding the processing and reporting of attitude assessment. The result of the questionnaire showed that $41.49 \%$ of elementary school teachers in Bekasi City understood the processing and reporting of attitude assessment, $52.57 \%$ with partial understanding, and $5.76 \%$ did not under- stand. It occurred in every teacher or classroom teacher.

Majority of elementary school teachers in Bekasi City did an attitude assessment by doing observation and making incidental records of students' good and bad attitude. The student with a good attitude was given rewards such as getting praised by the teacher. Meanwhile, students with bad records were given guidance until their attitude change. The development of students' bad attitude was recorded in the journal. Teachers had difficulties in collecting and inferring the short description of assessment from various indicators and techniques.

Classroom teachers had difficulties in recapitulating and inferring the short description. Inferring the attitude assessment was confusing, for example, when there is one student who gets different attitude score from different teachers and the scores are even opposite each other. The attitude score had not yet represented students' attitude, it consisted of only several indicators, and it was still general. This problem arose because the formulation of determining the predicate and description of attitude assessment had not yet explained explicitly in the guide book. Teachers hope the process of attitude assessment can be simplified so the results can be utilized appropriately. In the guidance book, it was explained that school had the authority to determine the criteria of attitude description, in fact, the school did not make the criteria for the reason that the direction on making the criteria had not yet included in the guide book. On his study, Setiadi (2016) recommended the government to simplify the Curriculum 2013 guidance book, to conduct socialization and training of attitude assessment, to conduct training of thematic learning assessment technique for elementary school teachers, and to guide teachers in analyzing instrument and revising test items.

Another problem in processing the attitude assessment was that there was an intervention from the stakeholders. In FGD, some teachers mentioned that there were principals who intervened the assessment by requiring the teachers to give a minimum 
score B (good) even when the students had a bad attitude, even though it could backfire the student itself.

\section{The Utilization and Follow-Up}

The results of attitude assessment were not optimally used. Teachers considered that the results were still general, so it could not be utilized optimally. The results should be described in details so students or parents could improve the attitude score that is still bad. Here is an example of the attitude description by a teacher: "Spiritual aspect score: Fauzan prayed regularly, be grateful, and was able to develop his religious tolerance. Social aspect score: Fauzan was very honest, confident, and needed guidance in discipline". Students or parents did not understand what it was meant by "very honest and needed guidance."

Description in the attitude assessment was considered meaningless by teachers. As in the students' report, it was only written "student was very obedient, very honest, needed guidance and counseling," this description was meaningless because student or parents were not specifically informed of students' attitude. It would be more meaningful if it were stated technically. For example, student was in need of guidance because he was often late, and influenced his friends for not attending school; students did not do Jumat prayer. By describing it specifically, both teachers, school, and parents could utilize and follow-up the report.

The teacher said that it would be meaningful if students' behavior were stated explicitly. For example, in the spiritual aspect score: Fauzan prayed regularly (praying and doing congregational prayer in an orderly manner), was grateful (for his meal even though it was not enough), and was able to develop his religious tolerance (befriended with students from different religions). Social aspect score: Fauzan was very honest (he found money at school and returned it to the teacher, he never cheated), confident (always answered teacher's questions loudly), and discipline (came to school on time, being patient while queuing).
The follow-up of attitude assessment is very important, so students can immediately change their bad attitude. In FGD, it was mentioned that the majority of teachers had done the follow-up. The steps in doing the follow-up of the attitude assessment results were: (1) the spiritual and social behavior being observed were recorded in teachers' journal, it was used as the followup by school; (2) teachers immediately did the follow-up of students' bad attitude by giving guidance; (3) classroom teachers could develop counseling and mentoring services for students had bad attitude; (4) if the students had bad attitude records and had not shown any positive change, the description of their attitude would be discussed in the teacher council meeting at the end of semester. The meeting decided on the predicate and description of students' attitude that should be written in the report and decided the follow-up for the students.

\section{Discussion}

The planning of attitude assessment is necessary. However, only some elementary school teachers in Bekasi City understood how to do the planning, especially on how to turn the attitude indicators into an instrument of the assessment and how to make a scoring rubric. It was because attitude assessment was a new addition in Curriculum 2013. Meanwhile, in the previous curriculum, teachers were not asked to conduct the attitude assessment (only observing and scoring). Besides, there are too many instruments to be mastered by teachers, namely unstructured observation form, structured observation form, spiritual and social journal, self-assessment form, and peer-assessment form. Teachers ability to understand the attitude assessment technique could affect the quality of the assessment. Based on these reasons, teachers suggested that the assessment done by all teachers is the observation technique only, while the classroom teacher does other techniques.

Curriculum 2013 emphasizes on students' involvement in the learning process. However, most students were passive during 
the learning process and made the learning atmosphere becoming less active. Therefore, some variables need to be added in the attitude assessment, namely the variable of accepting and responding, which are included in Bloom's Taxonomy affective assessment. Accepting refers to the ability to show attention and give a response to the appropriate stimulation and the ability to show attention and appreciation for others, for example: listen to and appreciate other's opinions. Besides, responding refers to students' affective involvement in the learning process, become participants and interested in the learning materials, such as asking questions, actively participating in the in-class discussion, etc.

There were several techniques in implementing attitude assessment during or outside the learning process, but there were only some elementary school teachers in Bekasi who understood the techniques. Most teachers conducted the attitude assessment through observation technique by making an incidental record. While interview, the selfassessment, and peer assessment were rarely used because the teacher did not really understand the techniques. Some reasons of the incomprehension mentioned by teachers were (1) teachers did not fully understand in how to make the self, and peer assessment instruments; (2) teachers were confused on deciding the final score (the final score was a combination of observation score, self, and peer assessment score); and (3) teachers felt that there was not enough time to conduct self and peer assessment.

Both teachers' and classroom teachers' understanding of processing the attitude assessment were still lack. Teachers had difficulties in collecting the records and inferring the short description of the assessment result from various indicators and assessment techniques. Meanwhile, the classroom teachers had difficulties in recapitulating and inferring the short description from several teachers and school residents. In FGD, some teachers mentioned that some principals required their teachers to give a minimum score of $\mathrm{B}$ (good) even when the students had a bad attitude.
The utilization of the attitude assessment results was not optimal. In the students' report, it was only written "student was very obedient, very honest, needed guidance and counseling," which was considered too general by teachers, so it could not be utilized by students or parents to conduct evaluation. Majority of teachers did an immediate follow-up of students' bad attitude by giving them guidance and counseling.

\section{Conclusion}

The implementation of attitude assessment which is conducted by teachers starting from the assessment planning, the implementation, the assessment results' processing, its' utilization, and the follow-up is not optimal. It is because of teachers' lack of understanding. Generally, the lack of understanding is because the attitude assessment is a new addition in Curriculum 2013, and in the previous curriculum, teachers were not explicitly asked to conduct the attitude assessment. Moreover, there were too many techniques of attitude assessment. It needed much time to learn, implement, and process the assessment. Curriculum 2013 emphasizes on students' involvement in the learning process. However, most students were passive during the learning process and made the learning atmosphere becoming less active, so the teachers need to think of a way to increase students' participation. The utilization of the attitude assessment was not optimal.

To optimize the implementation of attitude assessment in Curriculum 2013 for primary education level, researchers had summarized some recommendations obtained from the study, including: (1) schools are expected to provide independent training for the implementation of assessment in Curriculum 2013, because in the previous curriculum, teachers were not explicitly asked to conduct the attitude assessment; (2) MoEC is expected to change the regulation of the use of attitude assessment techniques, namely: the attitude assessment required to be done by each subject teacher is observation, while other required assessments are to be 
done by the classroom teacher, because teachers had difficulties in processing and formulating the attitude assessment combined from several techniques; (3) MoEC is expected to add more variables in attitude assessment especially in social aspects (KI2 ), accepting and responding. Accepting refers to the ability to show attention and give a response to the appropriate stimulation and the ability to show attention and appreciation for others. Meanwhile responding refers to students' affective involvement in the learning process, become participants and interested in the learning materials. It is in line with Curriculum 2013 that emphasizes on students' involvement in the learning process; (4) there should be a detailed and technical description of attitude assessment scoring in students' reports, for example student $\mathrm{X}$ are given $\mathrm{C}$ for the attitude score because he was late 30 times, 20 times did not come to school, etc. This description is more meaningful and can be utilized by students and parents.

\section{Acknowledgment}

This work is supported by the Center for Policy Research in Education and Culture, Research and Development Agency, Ministry of Education and Culture under the budget of Center for Policy Research, in 2018.

\section{References}

Directorate for the Development of Elementary School. (2016). Panduan penilaian untuk sekolah dasar. Jakarta: Kementerian Pendidikan dan Kebudayaan. Retrieved from http:// ditpsd.kemdikbud.go.id/wp-content/ uploads/2017/06/PanduanPenilaian-untuk-Sekolah-Dasar.pdf

Haryana, G., \& Gimin, G. (2015). Hambatan yang dihadapi guru ekonomi SMA dalam implementasi Kurikulum 2013 di Kota Pekanbaru. PEKBIS (Jurnal Pendidikan Ekonomi Dan Bisnis), 7(2), 146-151.
Hatmoko, W. (2016). 10 Faktor kesuksesan seseorang. Retrieved January 7, 2019, from https://ciptacendekia.com/for ums/topic/10-faktor-kesuksesanseseorang/

Mahmud, M. (2014). Kendala guru dalam melakukan penilaian pada proses pembelajaran kurikulum 2013 di Sekolah Dasar Gugus Delima Banda Aceh. Pesona Dasar (Jurnal Pendidikan Dasar Dan Humaniora), 2(3), 33-44. Retrieved from http://www.jurnal. unsyiah.ac.id/PEAR/article/view/74 97

Merta, I. M. E. D., Suarjana, I. M., \& Mahadewi, L. P. P. (2015). Analisis penilaian autentik menurut pembelajaran kurikulum 2013 pada kelas IV SD No. 4 Banyuasri. Journal PGSD Universitas Pendidikan Ganesha Jurusan PGSD, 3(1). Retrieved from https://ejournal.undiksha.ac.id/index .php/JJPGSD/article/viewFile/5818 $/ 4207$

Purnomo, Y. W. (2013). Keefektifan penilaian formatif terhadap hasil belajar matematika mahasiswa ditinjau dari motivasi belajar. In Seminar Nasional Matematika dan Pendidikan Matematika, in the theme of "Penguatan Peran Matematika dan Pendidikan Matematika untuk Indonesia yang Lebih Baik." Yogyakarta: Department of Mathematics Education, Faculty of Mathematics and Natural Sciences, Universitas Negeri Yogyakarta.

Regulation of the Minister of Education and Culture of Republic of Indonesia No. 23 of 2016 on Educational Assessment Standard (2016).

Retnawati, H. (2015). Hambatan guru matematika sekolah menengah pertama dalam menerapkan kurikulum baru. Jurnal Cakrawala Pendidikan, XXXIV(3), 390-403. https:// doi.org/10.21831/cp.v3i3.7694

Riscaputantri, A., \& Wening, S. (2018). Pengembangan instrumen penilaian 
afektif siswa kelas IV sekolah dasar di Kabupaten Klaten. Jurnal Penelitian Dan Evaluasi Pendidikan, 22(2), 231242. https://doi.org/10.21831/pep. v22i2.16885

Setiadi, H. (2016). Pelaksanaan penilaian pada kurikulum 2013. Jurnal Penelitian Dan Evaluasi Pendidikan, 20(2), 166178. https://doi.org/10.21831/pep. v20i2.7173

Sutama, S., Sandy, G. A., \& Fuadi, D. (2017). Pengelolaan penilaian autentik kurikulum 2013 mata pelajaran matematika di SMA. Jurnal Manajemen Pendidikan, 12(1), 105-114. https:// doi.org/10.23917/jmp.v12i1.2967

Utsman. (2014). Penilaian otentik berbasis kurikulum 2013. In Proceeding of Seminar Nasional Evaluasi Pendidikan, in the theme of "Pengembangan Pendidik: Implementasi Asesmen Otentik Pendidikan dalam
Rangka Meningkatkan Kompetensi dan Kinerja Professional Berkelanjutan". Semarang: Universitas Negeri Semarang.

Wuryani, W., \& Irham, M. (2014). Penilaian dalam perspektif Kurikulum 2013. Insania: Jurnal Pemikiran Alternatif Kependidikan, 19(1), 181-199. https:// doi.org/10.24090/INSANIA.V19I1.4 70

Yulia, L., Bakhtiar, B., \& Fauzi, F. (2017). Kendala guru dalam mengimplementasikan buku paket kurikulum 2013 di SD Negeri 50 Banda Aceh. Jurnal Ilmiab Mabasiswa Pendidikan Guru Sekolab Dasar, 2(1), 204-211. Retrieved from http:// www.jim.unsyiah.ac.id/pgsd/article/v iew/2549 